\title{
Botanical Gardens of Western Russia, Ukraine, Belarus, and Georgia
}

Botanical gardens in the western former Soviet Union (FSU) contain a rich diversity of horticultural plant germplasm, reflecting a long history of botanical interests. In addition, significant research continues on the physiology, genetics, and economic uses of these resources. We visited many of these gardens and met their directors and specialists during June 1990 (R.A.B.) and Aug. 1993 (S.H.J.) on trips organized by the Citizen Ambassador Program of People to People International. Gardens and arboreta visited included: Kirovsk, Russia $\left(68^{\circ} \mathrm{N}\right)$; St. Petersburg, Russia (formerly Leningrad, $\left.60^{\circ} \mathrm{N}\right)$; Moscow, Russia $\left(56^{\circ} \mathrm{N}\right)$; Minsk, Belarus $\left(54^{\circ} \mathrm{N}\right)$; Kiev, Ukraine $\left(51^{\circ} \mathrm{N}\right)$; Krasnodar, Russia $\left(45^{\circ} \mathrm{N}\right)$; and Tbilisi, Georgia $\left(42^{\circ} \mathrm{N}\right)$. The following account describes the plant resources and research emphases at each location and is organized along a northsouth transect (see Fig. 1).

Botanical gardens in the FSU have historically been owned, operated, and their public and research activities controlled by the central government. However, since the breakup of the union, government control and support of the gardens has greatly diminished. Although the gardens are more autonomous than in the past, they are struggling financially. Decaying facilities and low morale prevailed in most institutions we visited in 1990 during the peak of "glasnost," especially in the basic research institutions. This was less evident in those institutions with applied emphases or where the directors held some sway with party figures. These conditions were more widespread and evident at every site visited in 1993. Funds do not generally allow for "luxury" projects, such as mowing grass and operating

\begin{abstract}
Received for publication 12 July 1994 . Accepted for publication 20 July 1994. Travel was supported in part by the Univ. of Wisconsin-Stevens Point (SHJ) and Loyola Univ. of Chicago (RAB). Information in this paper was obtained from personal communication with botanical garden staff and public information literature provided by the respective botanical gardens. We acknowledge the helpful reviews provided by V. Thiesfeld, R. Freckmann, and E. Gasque, Dept. of Biology, Univ. of Wisconsin-Stevens Point. The cost of publishing this paper was defrayed in part by the payment of page charges. Under postal regulations, this paper therefore must be hereby marked advertisement solely to indicate this fact.
\end{abstract}

Front cover: (top left) Entrance to the PolarAlpine Botanical Garden, Kirovsk, Russia; (bottom left) water garden at Moscow State Univ. Botanical Garden, Moscow, Russia; (right, top to bottom) one of the many impressive glasshouses at the Komarov Botanical Inst. (KBI), St. Petersburg, Russia; Victoria amazonica Orb. inside a glasshouse at the KBI; variety trials at the Botanical Garden of the Belarus Academy of Science, Minsk. Photo credits: Top left, top right, and center right photographed by R.A.B. (1990); lower left and lower right photographed by S.H.J.(1993). decorative fountains, but the plant collections were immaculately maintained and in excellent condition. We were encouraged that some gardens are finding creative and successful ways to support themselves. Visiting or communicating with the staff of these gardens does not require a thorough knowledge of Russian. A conversational knowledge would certainly be helpful, but some employees in all of the gardens speak English. In all gardens that we visited, the staffs were very open, helpful, and appeared genuinely interested in scientific exchanges and collaborations.

\section{KIROVSK}

\section{Polar-Alpine Botanical Garden, Kola} Branch, Russian Academy of Sciences

The Polar-Alpine Botanical Garden (PABG) is situated near Lake Imandra on a mountainside outside the small industrial and agricultural city of Kirovsk. It is the northernmost botanical garden in the FSU and is located $\approx 230 \mathrm{~km}$ south of Murmansk (the largest city in the Arctic Circle) on the Kola Peninsula. The PABG is a spartan but beautiful 3.5$\mathrm{km}^{2}$ facility, including a main compound at $320 \mathrm{~m}$ above sea level (ASL), a specimen garden at $350 \mathrm{~m} \mathrm{ASL}$, and a nearby ecophysiology research station at $600 \mathrm{~m}$ ASL $(200 \mathrm{~m}$ above timber line). Established in 1931, the research activities of the PABG are divided into seven areas: plant introduction (largest of the seven), flora and natural resources, plant physiology, soil and soil microbiology, dendrology, landscape architecture/ornamental horticulture, and plant pathology and biological control. The activities of the resident research staff are augmented by students from universities in Petrozavodsk and St. Petersburg.

Moving up the mountainside from the main compound, one enters a mixed deciduous/ coniferous forest zone at $310 \mathrm{~m}$ ASL. The next feature, at $350 \mathrm{~m} \mathrm{ASL}$, is the specimen garden, a large cultivated space containing more than 1320 plantings. Claytonia sibirica var. asarifolia L., native to the United States, is prolific and was jokingly referred to as "The American Aggressor" by the garden staff. The increasingly sparse, short alpine tree and shrub vegetation gives way to the tundra at $\approx 400 \mathrm{~m}$ ASL. Above $1000 \mathrm{~m}$ ASL is polar desert where snow was widespread during late June 1990 . This elevation receives $\approx 2 \mathrm{~m}$ of snowfall a year and the mountain has no glaciers or permafrost.

The main facility is geared toward collection, propagation, and cultivation of alpine and polar plant species from the region and the world. The small facility at $600 \mathrm{~m}$ ASL conducts in situ measurements of $\mathrm{CO}_{2}$ gas exchange in the tundra using closed gas-ex- change chambers. Other PABG laboratories investigate the effects of air pollutants (mainly $\mathrm{SO}_{2}$ and particulates) and the cultivation and use of nonsymbiotic, nitrogen-fixing Cyanobacteria as soil amendments. The region's soils are acidic (pH3.5-5) and of poor agricultural quality, thus requiring large amounts of fertilizer and lime. This poor soil quality is exacerbated by the smoke stack and waste water output of aging smelters on the Kola Peninsula. Travel to the PABG from Murmansk takes one past a nickel smelter surrounded by a smoking, reeking wasteland of twisted, stunted trees, slag piles, and acrid poolsgrim testimony to the historic lack of environmental concern displayed by rulers seeking industrial output at all costs.

Contacts: L.M. Lukyanova (director) and Alexander Choorikov (vice director), 84230 Botanical Garden, Kirovsk, Murmansk Region, Russia; phone $011+7$ + 02-04-75

\section{ST. PETERSBURG}

\section{Komarov Botanical Institute of the Russian Academy of Sciences}

The Komarov Institute Botanic Garden (KIBG) was founded in 1714 as the pharmacy garden of Peter the Great. The collection expanded quickly due to extensive explorations of the flora of Russia and foreign countries. In 1905 more than 27,793 taxa were represented in the garden, and by 1930, when it was transferred to the Academy of Sciences, it was the main botanical garden in the FSU. During the siege of St. Petersburg (then Leningrad) in World War II, most of the greenhouses were destroyed and most of the plants perished during Winter 1941-42. Only 300 of the original 5000 indoor species survived, but heroic efforts during and after the war have returned the institute's conservatory, herbarium, and library to one of the best in Europe. The KIBG now covers $\approx 0.2 \mathrm{~km}^{2}$ and features more than 12,000 taxa belonging to 313 families, 2245 genera, and more than 8000 species.

The outdoor collection of the KIBG occupies $0.17 \mathrm{~km}^{2}$ and includes 713 species from 123 genera and 43 families. Nearly 600 rose cultivars are evaluated for ornamental quality and winter hardiness. The KIBG staff $(\approx 700$ people, 400 scientists) channels much of its effort into plant introductions and the development of horticultural cultivars. An extensive collection of alpine, subalpine, and other plants found on rocky sites contains 2000 species of 433 genera in 93 families, including several rare and endangered species. More than 600 species of bulb and corm plants are maintained, including a display of 500 species and cultivars used in landscaping. The tulip collection contains more than 100 specimens, many that were first tested here for hardiness above $60^{\circ} \mathrm{N}$. Many outdoor plantings are organized into regional assemblages, which provides an exceptional opportunity to "travel" to many distant and far-off habitats (in Russia and foreign countries) that have been largely

continued on p. 1105 
unseen by western botanists, including the mountain regions of Caucasus, Kolyma, and Himalaya; the desolate eastern regions of the FSU; and southeast Asia. There is also a substantial nursery where seeds are produced for exchanges with other institutions.

The extensive tropical and subtropical plant collection is maintained in 13 greenhouses totaling $5300 \mathrm{~m}^{2}$ and contains 662 genera in 143 families. Of special interest are collections of palms (100 species), aroids (117 species), bromeliads (112 species), cycads, water lilies, tropical food plants, and economically useful tropical plants. Tropical plants not typically found in botanical gardens include several mangrove genera and all cycad genera, including the rare Cuban species Microcycas calocoma Miq. Large specimens of Cycas circinalis L. and Cycas revoluta Thunb. are more than 100 years old. The orchid collection contains 435 taxa in 108 genera of the family Orchidaceae, including recently collected Vietnamese material. The subtropical plant collection, occupying $3355 \mathrm{~m}^{2}$ of greenhouse space, includes 662 genera in 166 families. The most prized species is Platanus kerrii Gagnepain, first introduced to cultivation at the KIBG. Fern and moss collections are currently being established. The succulent plant collection contains 250 genera in 30 families, including 1000 species of cacti. Among the most valuable specimens are a 115-year-old Euphorbia ingens E.H. Mey. and an 84-year-old Cereus peruvianus $\mathrm{L}$.

Contacts: Dimitry Geltmann (assistant director, Herbarium), Prof. Popov Street, 2, St. Petersburg, Russia, or Tatyana R. Kuzmina (executive director), St. Petersburg Association for International Cooperation, Society for Cultural and Business Contacts, Fontanka, 21, St. Petersburg, 191011, Russia; phone 011 + 7 + 812-311-40-84, fax 011-7-812-311-40-89.

\section{MOSCOW}

Main Botanical Gardens of the Russian Academy of Sciences

The Main Botanical Garden (MBG) is one of Europe's largest, occupying $3.6 \mathrm{~km}^{2}$ inside Moscow's city limits. Established in 1945 by Stalin, the site is in a picturesque area of the city, adjacent to the Timiryazev Institute of Plant Physiology and traversed by the Yauza, Likhoborka, and Kamenka rivers. The garden's main goals are to preserve the natural Russian flora, and to improve and propagate the regional flora, enriching it with new varieties from other areas. The native Russian plant collection is unparalleled, with more than 3000 species.

Five display areas present the major geographical and floral zones of the FSU. They include the European region, Central Asia, Siberia, Caucasus, and the Far East. European regional plants include those of forest-steppe and steppe zones. Plants native to the Carpathians occupy the forest fringe. Flora from the mixed forests of the Russian plain are
FIG. 1, LINE ART SHOOT at $100 \%$

\section{DROP KEYLINE}

Fig. 1. A portion of the western former Soviet Union. Botanical gardens were visited in all cities indicated. Scale: $1 \mathrm{~cm}=200 \mathrm{~km}$.

adjacent to a small pond and swamp. The flora of Central Asia are grouped into broad-leaved forests, juniper groves, spruce forests, forbs, plants of the highland steppes, Alpine meadows, and deserts. Extensive collections of grasses, Allium, and tamarisks have been planted. The Siberian plant collection contains taiga species such as Siberian firs, spruces and stone pines, larches, and bear's onion (scurvy remedy in Siberia). An artificial hill contains species of the Caucasus. Alpine meadow and scree plants are found on the slopes. The collection occupying the largest area in the MBG is that of the Far Eastern region.
An especially valuable collection of broadleaved forest specimens from central European Russia is found in the oak grove reserve. This $0.6-\mathrm{km}^{2}$ oak grove, closed to the public, is likely the most typical and well-preserved Russian oak grove in the region. This oak grove contains English oaks (Quercus robur L.) more than 200 years old, aspen (Populus), birch (Betula), larch (Larix), maple (Acer), basswood (Tilia), elm (Ulmus), Polygonum, and mountain ash (Sorbus). The forest appears to be healthy, with no evidence yet of oak wilt or gypsy moth.

The northern part of the MBG, a $0.75-\mathrm{km}^{2}$ arboretum, contains 2000 varieties of woody 
plants. Specimens adapted to the region's climate include hornbeam (Carpinus), Japanese quince (Chaenomeles), late honeysuckle (Lonicera), Cotoneaster horizontalis Decne., and yew (Taxus). A cultivated flora region emphasizes the origin and evolution of cultivated plants and contains more than 2200 species and cultivars, including fruits and vegetables with their wild relatives, medicinal plants, and industrial plants. Selection methods, similar to those used to develop modern tomato (Lycopersicon esculentum L.) cultivars, are illustrated, as are wide hybridizations such as pear-cotoneaster, and pear-mountain ash varieties.

Most visitors are attracted to the decorative plants section. It contains the largest collection of roses in Europe. More than 2600 cultivars developed by the MBG include tea hybrids, floribundas, climbers, perpetuals, and miniatures. The rosarium contains 250 of the most beautiful and hardy cultivars that are recommended for landscaping. An impressive collection of 350 lilac cultivars is also found in this section. Valuable bulb collections include 320 tulip cultivars and 230 Narcissus cultivars, as well as hyacinths, lilies, and crocuses. The perennial garden contains 93 species, grown to provide planting recommendations to the city. It includes 60 Astilbe varieties and 80 Hemeracalis varieties, including some U.S. imports. The staff continues to study the adaptability of the plants they recommend for city use, especially their response to pollution, water, and other anthropogenic stresses. The herbaceous perennial collection includes 350 iris, 558 peony, 950 gladiolus, 300 phlox, and 300 dahlia cultivars. Rare perennial collections contain stonecrops, saxifrages, lilies-ofthe-valley, Astilbe, larkspurs, goldenrods, bluebells, day lilies, and 65 species of fern.

The MBG maintains $6000 \mathrm{~m}^{2}$ under glass, containing more than 4500 species and forms of tropical and subtropical plants. On display are nutritive, industrial, and medicinal plants collected from various regions of the world. Impressive collections of begonia, Streptocarpus, and African violet also are maintained. Other unusual specimens include East Indian pitcher plants (Nepenthes), South American water lily (Victoria cruziana Orb.), and tree ferns. The extensive orchid collection emphasizes an interest in the collection and maintenance of wild germplasm.

The MBG collections provide invaluable research resources. Most research concentrates on plant introduction and acclimatization, and the use of plants in the landscape. Another research area is the propagation and reintroduction of rare and endangered plant species. Special emphasis is put on collection, protection, and use of wild relatives of cultivated plants. Wide hybridization studies have resulted in the production of perennial wheatquackgrass hybrids, triticale, and tetraploid rye. Additional research areas include disease and stress tolerance, and the use of plant growth regulators to alter flowering patterns in ornamental and fruit crops. Finally, the MBG is active in screening cultivars to make recommendations for government and private plantings. Ten departments span diverse interests: Herbarium, Dendrology, Cultivated Flora, Floriculture, Tropical Flora, Seed Physiology, Plant Physiology, Plant Protection, Wide Hybridization, and Promotion of Scientific Achievements. The MBG herbarium contains 300,000 specimens and has a library of 170,000 botanical books. Researchers are developing a computerized database with useful plants of the tropics and subtropics.

Contact: Rimma A. Karpisonova, Botanischeskaya ul., 4 Moscow, 127276, Russia; phone 011-7-095-218-7213.

\section{Moscow State Univ. Botanical Garden}

Although the arboretum is small $(87,000$ $\mathrm{m}^{2}$ ), it contains more than 1000 woody species and forms, encompassing 143 genera in 48 families. The garden was established in 1805 , but the first woody plantings were not made until 1951. The garden is organized by geographic zones: European coniferous, mixed, and highland forests; eastern and western North American forests; Central Asian highland forests; Siberian forests; Caucasus Mountains; far eastern Russian forests; Japan; and China. Efforts continue to expand the collection of woody plants through exchanges with foreign gardens. Displays include 33 maple species (Acer), 34 birch species (Betula), and 34 mountain ash species (Sorbus). Greenhouse collections date to the late 1700 s and have been expanded via private donations and exchanges with other gardens. Included in these collections are conifers, ferns, succulents, lilies, and tropical aroideous and begoniaceous species. A valuable collection of palms and cycads includes 150 - to 250 -year-old plants.

Pesticides cannot be stored within Moscow city limits; therefore, chemical inputs are limited and biological control methods, such as pheromone traps, are used. Fertilizer is obtained mostly in the form of manure from the Moscow circus and local collective farms.

\section{MINSK}

\section{Botanical Garden of the Belarus Academy of Science}

This garden is 60 years old and covers 0.96 $\mathrm{km}^{2}$. The collection contains 10,000 varieties: 5500 decorative, 1600 tree, and 2500 tropical and subtropical; the remainder are medicinal and fruit varieties. Geographic regions, such as Europe, Caucasus, Central Asia, the Far East, and Belarus, are separated by tree-lined boulevards radiating from a central garden, creating a unique and impressive display. Boulevard trees include Manchurian walnut (Juglans mandshurica Maxim.), silver maple (Acer saccharinum L.), European white birch (Betula pendula Roth), littleleaf linden (Tilia cordata Mill.), Norway spruce (Picea abies L.), green ash (Fraxinus pennsylvanica Marsh.), English oak (Quercus robur L.), and mulberry (Morus alba L.). The lilac garden contains 170 German, French, and Belarussian varieties.

Research emphasizes new plant introduc- tion, landscape architecture, and ecology. Eight laboratories concentrate on the introduction and selection of decorative plants, introduction and selection of woody plants, natural resistance, biochemistry and physiology, plant protection, ecological physiology, micropropagation, and technical and industrial aspects of horticulture. Reforestation of Belarus is a highpriority project, but propagation is often by cuttings because seed production is scarce. Selection studies concentrate on frost, pest, and pollution resistance, and results include the development of a mildew-resistant Phlox variety.

There is considerable activity in the study of medicinal properties of plants. Oil from mountain ash fruits is used to enhance wound healing. Aralia root extracts are used to enhance the immune system and to reduce effects of radiation sickness. Interest in radiation sickness remedies is very high here, since Minsk received much of the Chernobyl fallout. Aronia melanocarpa Michx. is being developed as a medicinal plant to treat hypertension and decrease blood pressure. Ginseng (Panax) is also grown for its medicinal properties.

This garden appears to be financially stable, mainly because it generates funds through the sale of plant material. It is affiliated with a 0.5 $\mathrm{km}^{2}$ fruit introduction station, located $250 \mathrm{~km}$ west of Minsk, that propagates new varieties of blueberries, cranberries, and currants. The station produces and sells 100 million cuttings per year to pay for research expenses. Additionally, the garden's tree nursery propagates and sells 150,000 cuttings annually.

Contact: Eugene A. Sidorovitch (director), 2a Surganova St., Minsk, 220600, Belarus; phone 011-7-017-39-44-87 or 011-7-017-3952-94.

\section{KIEV}

\section{Botanical Garden of the Ukraine Academy of Sciences}

Founded in 1935, the garden occupies 1.32 $\mathrm{km}^{2}$ and contains 12,000 plant varieties. About $65 \%$ of the garden is devoted to native plants of the FSU; the remainder contains cultivated species. The major part of the garden is laid out according to Ukrainian flora: Crimea, Carpathian Mountains, forests, and steppes. The garden also has representative species from the FSU, including Caucasus, Central Asia, and the Far East.

An interest in floriculture is obvious, with extensive selection plots of dahlias and roses. Shrub and garden roses, rather than those for cut stems, are the focus of selection efforts. Interestingly, no plant variety protection system exists, but efforts are underway to develop one. An impressive collection of 100 lilac varieties draws 225,000 visitors daily during the spring bloom. A vast collection of 350 medicinal plant varieties is maintained. Another garden priority is to propagate endangered species, including endemic orchids, and to reintroduce them to their native habitat. The pomology section includes dramatic examples 
of apples and pears pruned and trained into bushes, arches, pyramidal forms, and espaliers. The conifer collection contains 165 varieties, including Colorado spruce (Picea pungens Engelm.) from the United States, Norway spruce (Picea abies L.), and juniper (Juniperus). The greenhouses contain more than 1000 varieties of tropical plants.

Research areas of this facility include dendrology, floriculture, tropical plants, agronomic and horticultural plants, pomology, physiology, ecology, and medicinal plants. Biochemical research currently focuses on: development of nonalcoholic soft drinks with medicinal properties; treatment of abdominal, intestinal, and heart disease; and the production of juices that remove heavy metals from the body. Garden researchers have worked with cosmonauts to develop plants that will survive during space travel. One interesting discussion revealed that, while ground-dwelling species of orchids died in space, all epiphytic species survived missions lasting up to 165 days. The need to conserve and use available resources efficiently was apparent in the greenhouses. For example, the potting mix includes waste products from local textile industries. Apparently, the dyes are not toxic and some actually seem to enhance plant growth. Mercury lights are suspended in the orchid house, but the high cost of electricity prohibits their use. Lath provides shading over the glass.

Contact:TatjanaMikhajlovna Cherevchenko (director), Timiryazevskaya st. 1, Kiev, 252014, Ukraine SSR; phone 011-7-044-29541-05 or 011-7-044-295-26-27.

\section{Kiev State Univ. Botanical Garden}

Kiev State Univ. opened this garden in 1839 for student training. It occupies $0.22 \mathrm{~km}^{2}$ and contains 8000 varieties including 4000 tropical and subtropical varieties, and 300 aquatic plant varieties. One emphasis is the collection and maintenance of heirloom varieties. The garden also maintains a large collection of xerophytes. Although many plants were lost during Nazi occupation in World War II, the outdoor gardens include Ginkgo, Magnolia, Cotoneaster, Quercus, and Pseudotsuga menziesii (Mirb.). The greenhouses include one building that is 32 meters high and contains some tropical plants more than 200 years old. Most greenhouse collections are from South America, Asia, and Africa.

Contact: Vasiliy V. Kapustjan (manager, Botanical Garden), 1, Kominterna Str., Kiev, 32, Ukraine SSR; phone 011-7-044-224-29. 06.

\section{KRASNODAR}

\section{Kuban State Univ. Botanical Garden}

Krasnodar, a city of $\approx 750,000$, is located on the Kuban River $100 \mathrm{~km}$ inland from its mouth on the eastern shores of the Black Sea. The small garden $\left(0.12 \mathrm{~km}^{2}\right)$, established in 1919 , is devoted primarily to the study of the flora of the northern Caucasus region and the coastal Black Sea habitats. The garden contains more than 5000 varieties from 2000 species, mostly tropical and subtropical, nearly all of it maintained outdoors. The university has an herbarium collection numbering 3000 species and 15,000 specimens.

The university maintains a field station with a small experimental garden at Novorossiysk on the Black Sea. Novorossiysk is one of several popular resort towns, including Sochi (popular with the country's rulers), along the Black Sea's eastern shore. Besides basic regional ecological and floristic work, the university and garden staff maintain a focus on the collection, adaptation, and cultivation of pollution- and anthropogenic-stresstolerant plants for urban landscape use in these heavily used seaside resorts. Additional research includes viticulture and floriculture to enhance the economic exploitation of the region's sub-Mediterranean climate.

Contacts: Vladimir Nagalevsky (dean) or Sergeeva Balentina (herbarium curator), K. Libknecht 149, Krasnodar, 350640, Russia; phone 011-7-33-26-36.

\section{TBILISI}

\section{Botanical Institute of Tbilisi, Georgian Academy of Sciences}

The Botanical Institute of Tbilisi (BIT), which includes the botanical gardens, was established in 1894. It grew from Tbilisi's distinguished history as a leading regional center of botanical study. Prince Babushin of the royal family described the flora of Georgia, and many Russian and European botanists collected in Georgia and the Caucasus early in the 19th century. The present-day BIT is organized into nine disciplines: systematics; geography of plants; phycology; horticulture; plant physiology; geobotany of forests, meadows, and steppes; plant ecology; plant cartography; and photography. BIT runs two mountain and alpine field stations that separately maintain an alpine collection of more than 1000 specimens. The BIT herbarium claims a collection of more than one million specimens, including $>1000$ type species. The BIT has incorporated many old collections, and a sample of their more treasured specimens includes a Trigonella collected in 1828 and a Fibigia collected in 1844. The Flora of Georgia (both editions) and the Red Book of the Georgian SSR were published by the BIT.

The garden is not organized as a formal botanical garden, rather it is maintained in regional "departments" within a larger, forested mountainside preserve. The garden mirrors the BIT emphasis on Caucasian, middle Asian, Iranian, and Turkish floras. Nearly 8000 varieties of 1500 genera are maintained mostly outdoors. Many interesting Caucasian plants are found in the Dept. of Caucasian Endemics: Iris caucasica (Hoffmans), Convallaria; Paeonia caucasica L.; hybrids of Tulipa,Abies Nordmanniana (Steven) (Caucasian fir), and Abies numidica DeLannoy ex Carrière) (Algerian fir); regional maples; campanulas; and Brunnera macrophylla (Adams).

Contacts: Giorgi Nachuzrishvili (director) or Zaira Gviniavidze (herbarium curator), Georgian Academy of Science, Tbilisi Botanical Institute, Tbilisi, Georgia.

Shelley H. Jansky and Robert A. Bell Dept. of Biology Univ. of Wisconsin-Stevens Point Stevens Point, WI 54481 